\title{
STRATEGIES TO IMPROVE HISTORICALLY DISADVANTAGED UNIVERSITY STAFF'S WELLBEING AND ADMINISTRATION OF ACADEMIC PROGRAMMES DURING COVID-19: A DESCRIPTIVE SURVEY STUDY
}

\author{
M. Makgahlela* \\ Department of Psychology \\ https://orcid.org/0000-0003-4973-5692
}

\section{T. Mothiba*}

Faculty of Health Sciences

https://orcid.org/0000-0001-8654-3097

\section{P. M. Mphekgwana*}

Research Administration and Development

https://orcid.org/0000-0002-3068-9406

\section{Makhado}

Department of Public Health

University of Venda

Thohoyandou, South Africa

https://orcid.org/0000-0003-1689-9308

\section{Selepe*}

Centre for Student Counseling and Development

https://orcid.org/0000-0001-8051-5511

\section{J. P. Mokwena*}

Department of Psychology

https://orcid.org/0000-0003-0834-0758

*University of Limpopo

Sovenga, South Africa

\section{ABSTRACT}

The coronavirus (COVID-19) pandemic has brought the world to a standstill, impacting negatively on human mortality and morbidity. Currently, most countries are on a national lockdown as a way of curbing the rapid spread of the virus. Although desirable, nationwide lockdown continues to hamper the smooth running of the government's key strategic sectors including the schooling system. In this descriptive qualitative study, we explored university staff ( $n=87$; Mean $_{\text {age }}=38.54$; males $=50.6 \%$, females $=49.4 \%$ ) views on strategies that could improve their wellbeing and 
administration of academic programmes during-and-immediately after the COVID-19 national lockdown. Participants were sampled conveniently and responded to an open-ended questionnaire online. The participating staff recommended five key strategies that were thematically analysed, which are as follows: a) improved communication; b) provision of efficient ICT infrastructure; c) consideration of compensatory academic measures; d) on-campus COVID19 risk management strategy; and e) provision of online and on-campus psychological services. Based on these findings, it is recommended that the historically disadvantaged universities should consider implementing strategies for enhancing the staff's wellbeing and administration of academic activities. However, whether the suggested strategies could yield positive results, postimplementation evaluation research may be needed. For future preparedness, present findings imply that institutions of higher learning need to put in place contingency plans for efficient communication in times of crises similar to COVID-19 while investing in efficient ICT infrastructure for remote learning, teaching, and research.

Keywords: COVID-19, coronavirus, national lockdown, higher education, strategies of learning, historically disadvantaged universities

\section{INTRODUCTION}

The coronavirus (COVID-19) pandemic has brought the world to a standstill. The greatest challenge thus far has been the virus' impact on human mortality and morbidity (World Health Organisation [WHO] 2020). To contain the spread of the disease, many countries, such as South Africa has implemented a nationwide lockdown. Regrettably, nationwide lockdowns have disrupted the smooth running of national key strategic sectors such as the economy, health, and schooling systems (Mahaye 2020; Helmich and Bloem 2020). For instance, the pandemic had an impact on an increasing number of students worldwide, i.e., more than 1.6 billion learners' education has been impacted (UNESCO 2020). Generally, the unintended economic, physical, and psychosocial consequences of the virus are on an unprecedented scale (WHO 2020). Thus, the COVID-19 impact is continuing since there's no cure or vaccine for the virus as yet. In the same vein, empirically derived strategies or measures to guide governments and in particular, the institutions of higher learning in rural Africa on how best to respond to the pandemic are lacking (United Nations 2020).

In South Africa like in several African countries, since March 2020 (see South African Government COVID-19 Gazette 2020), the economy, health, and education systems have not been running smoothly owing to the COVID-9 pandemic.Academic programmes have been disrupted abruptly, with about 200 million learners out of school in the continent (Mahaye 2020). Mahaye further suggests that, in South Africa, more than 1.1 million learners in higher institutions of learning continue to be affected by the disease. The ministry of education continues to advise the institutions of higher learning on the running of academic programmes, especially priority 
programmes although not on full capacity. To keep students on track, remote learning is the most preferred and advocated mode of delivery since it maintains social distancing, therefore, reducing the spread of COVID-19 (Cowling et al. 2020; Ferguson et al. 2020; Lin, Lee, and Lye 2020; Viner et al. 2020). Although this is desirable under the circumstances, not all institutions of higher learning were prepared to run academic programmes remotely (Mahaye 2020). If measures such as social distancing and school closures do indeed contain the spread of COVID-19, studies yield varying results possibly due to timing issues, methodological issues, and lack of pre- and post-intervention studies (Viner et al. 2020). In the same vein, unlike those institutions in which remote learning is part of their academic culture, most universities in Sub-Saharan Africa like the present study setting may struggle to offer lessons remotely (Wyres and Taylor 2020; Aborode et al. 2020). This is because efficiency in remote learning is amongst others dependent on preparedness, technological tools, and overall student support infrastructure (Ray 2020). In light of this imperative, disadvantaged universities whose majority student base come from impoverished communities may struggle. Firstly, to avail an efficient ICT infrastructure for use on time, and secondly, students may struggle to gain access to remote learning technologies due to lack of personal ICT gadgets (e.g., laptops, smartphones), and poor ICT network connectivity in rural areas (Aborode et al. 2020; Mahaye 2020; UNESCO 2020).

Notwithstanding the COVID-19 crisis, failure and/or unfair access to education constitutes a gross constitutional infringement since in South Africa every student has the right to access quality education. It, therefore, becomes prudent for the government and all sectors of the society to mitigate this potential human right violation by amongst others paying closer attention to the needs of historically disadvantaged universities and students during COVID-19 pandemic. Despite the noted realities including the race to finding COVID-19 vaccine and cure, all stakeholders need to continue searching for novel strategies and ways to mitigate the nefarious impact of the virus on the wellbeing of all of humanity (Aborode et al. 2020; Mahaye 2020).

\section{Goal of the study}

In light of the background, the present study explored and described staff members' views on strategies that could improve their wellbeing and administration of academic programmes during and immediately after the COVID-19 nationwide lockdown in a historically disadvantaged university.

\section{METHODOLOGY}




\section{Study design}

The present study exploits the qualitative dataset generated from a bigger descriptive survey study with the participation of rural university staff and students from a historically disadvantaged university. For the main study, we triangulated methods of data collection by employing quantitative and qualitative methods. Qualitative data presented in this study were generated with two open-ended questions which sought to elicit staff members' needs and suggestions to improve their wellbeing and administration of academic programmes during and immediately after COVID-19 nationwide lockdown. The participating staff was sampled through the convenience sampling strategy.

\section{Study population, data-collection and procedure}

The population eligible for this study was the academic and support staff under the employ of the university. Data were collected with a self-administered, brief open-ended questionnaire that was circulated electronically. Upon observances of ethical and gate-keeper protocols, we approached the university communication and marketing liaison officer to send out the electronic questionnaire via an email platform using the official university email list database. For a broader reach, we also shared the survey link via electronic media applications, such as WhatsApp and Facebook. Upon receiving the survey link, participants were informed of the study purpose, ethical imperatives, and those agreeing to participate were prompted to give consent and complete the questionnaire online. A total of 87 staff members (see Table 1), i.e., 59 academics and 28 support staff completed the questionnaire. Data were collected over a period of 3 weeks (21 June to 9 July 2020), upon which the survey questionnaire was closed.

\section{Ethical considerations}

The institutional representative body (TREC/102/2020: PG) cleared this study concerning ethics. To gain access to university staff, gate-keeper permission was granted by the university registrar. An electronic informed consent form was embedded in the online questionnaire detailing the nature of the study, potential ethical issues, and clarity on the voluntary nature of the study including participants' freedom to withdraw from the study at any given point. Additionally, we readily made available a contact list of governmental and non-governmental mental health organisations rendering online services for their use whenever a need arose. We availed a contact number of a university-based counselling psychologist to be contacted if participants struggled to access online service providers. 


\section{Data analysis}

Demographic information of participants was isolated from the data-corpus, and frequencies were generated using the Statistical Programme for Social Sciences (SPPS version 26.0). Qualitative generated data were analysed thematically. We initially read through the generated dataset against the questions posed to participants to get a general understanding of their responses. Subsequently, we went through the responses now coding the data. The generated codes were later used to develop themes. The team members reviewed the initial themes generated and circulated them for input. For trustworthiness (King and Horrocks 2010), the research team discussed and finalised the themes via a remote platform (see Table 2).

\section{FINDINGS AND DISCUSSION}

Herein we present demographic information of participants (see Table 1). Subsequently, we present and discuss five generic strategies to emerge from the analysed data. For quality purposes, we have appended the recommended strategies with their supporting extracts (see Table 2 in Appendix).

Table 1: Demographic information of study participants

\begin{tabular}{|c|c|c|c|}
\hline Variables & & Frequency / mean & $\% / S D$ \\
\hline Staff Type & $\begin{array}{l}\text { Academic } \\
\text { Support }\end{array}$ & $\begin{array}{l}59 \\
28\end{array}$ & $\begin{array}{l}68 \\
32\end{array}$ \\
\hline Gender & $\begin{array}{l}\text { Male } \\
\text { Female }\end{array}$ & $\begin{array}{l}44 \\
43\end{array}$ & $\begin{array}{l}51 \\
49\end{array}$ \\
\hline Age & $\begin{array}{l}20-30 \\
31-40 \\
41-50 \\
51-60 \\
\geq 61\end{array}$ & $\begin{array}{c}\mathbf{3 8 . 5 4} \\
27 \\
34 \\
15 \\
15 \\
6\end{array}$ & $\begin{array}{c}11.74 \\
28 \\
35 \\
15 \\
15 \\
6\end{array}$ \\
\hline Marital Status & $\begin{array}{l}\text { Single } \\
\text { Married } \\
\text { Divorced } \\
\text { Widowed } \\
\text { Separated }\end{array}$ & $\begin{array}{c}46 \\
34 \\
2 \\
3 \\
1\end{array}$ & $\begin{array}{c}53 \\
40 \\
2 \\
3 \\
1\end{array}$ \\
\hline Residential & $\begin{array}{l}\text { Urban } \\
\text { Peri-Urban } \\
\text { Township } \\
\text { Rural }\end{array}$ & $\begin{array}{l}33 \\
10 \\
20 \\
24\end{array}$ & $\begin{array}{l}38 \\
11 \\
23 \\
28\end{array}$ \\
\hline Highest level of Education & $\begin{array}{l}\text { Matric/ higher education certificate } \\
\text { 1st to 2nd level } \\
\text { 3rd to 4th level } \\
\text { Postgraduate } \\
\text { Other }\end{array}$ & $\begin{array}{c}3 \\
1 \\
5 \\
74 \\
4\end{array}$ & $\begin{array}{c}3 \\
1 \\
6 \\
85 \\
5\end{array}$ \\
\hline
\end{tabular}

As evident in Table 1, most of the participating staff were academics (67.8\%). In their majority, participants aged between $31-40$ years (35\%) followed by those aged $20-30$ years $(28 \%)$. Most participants were single (53\%), held a post-graduate qualification (85\%), and were residing in 
urban areas $(38 \%)$.

\section{Strategies proposed by staff members}

Participating staff members suggested five key strategies (see table 2 appended) which they felt the university needed to implement to mitigate COVID-19 impacts. Below are strategies proposed and discussed:

\section{Development of COVID-19 communication strategy}

With this strategy, participants suggested that the university executive management needed to develop a COVID-19 communication strategy, which amongst others considered the following:

- Clear guidelines should be provided on the running of academic programmes during the nationwide lockdown;

- University stakeholders should be regularly updated on any important developments;

- All university stakeholders should have a provision for consultative forums;

- Regular communication and support from Head of Departments to departmental staff members was also identified as imperative; and

- Streamlined communication from management to all stakeholders including prioritising support staff.

The participants felt that if such an efficient and sustained communication strategy was put in place, it would enhance their discharge of duties during the pandemic. For instance, the support staff felt that the management did not prioritise communication with them, which indirectly impacted how they responded to academic staff's needs. This finding supports previous studies which highlighted the importance of direct and clear communication in times of emergencies such as COVID-19 (Mahaye 2020; UNESCO 2020).

\section{Provision of efficient Information Communication Technologies (ICTs) infrastructure for remote learning and research}

One of the key strategies recommended for the enhancement of staffs' administration of academic programmes during COVID-19 was the provision of efficient ICT infrastructure (UNESCO 2020). Amongst others, the university needed to speed up the procurement of fast connectivity internet services, including the provision of IT hardware equipment such as laptops to enhance remote learning. In this way, the staff could be able to deliver services timeously 
and reliably including conducting research remotely. However, since learning is a two-way process between lecturers and students, how the university would manage to ensure that each student has access to reliable internet services and ICT equipment may be another challenge needing attention. In support, UNESCO research reported that between 82-89 per cent of students in rural sub-Saharan Africa neither have personal computers or access to the internet at home (UNESCO 2020). The results also suggested that there's a need for continued training and support of staff on the use of online systems for teaching, supervision, and research. This perhaps supports Ray's (2020) view that for remote learning to be possible, the most significant elements of the structure that are required are: time, communication, technology, and lesson design. COVID-19 has caught institutions off guard; hence, it is unclear if the implementation of infrastructure development for disadvantaged universities is likely to occur. We can only speculate that the odds are against them. Nonetheless, for future preparedness, the results displayed that the university needed to maintain this strategy and built on it. In this way, COVID-19 indirectly presents an opportunity for rural sub-Saharan African universities to speed up the re-organisation of their systems of learning to incorporate ICT systems permanently for equal access to education by students (Aborode et al. 2020).

\section{Implementation of compensatory academic measures for students}

The results further displayed that to save the 2020 academic programme, the university needed to consider implementing the following compensatory academic measures to support students:

- Consider extending the 2020 university academic calendar;

- $\quad$ Ensuring or availing academic support, providing resources to students and a timeous response;

- $\quad$ Considering the revision of the 2020 examinations timetable;

- $\quad$ Consider employing part-time lecturers to offer support to catch-up on the lost time; and;

- $\quad$ Offering online research programmes and support to post-graduate students.

Some of the above measures, especially on the need for a revision of the exam timetable expresses a concern highlighted by some participants, which are; should exams be carried out as per initial examination timetable, there's a concern from academic staff members that there could be a high student failure rate. Unfortunately, no empirical studies are traceable in the literature supporting the effectiveness of academic compensatory measures suggested by staff members from this historically disadvantaged university. Of noteworthy, is that in a review 
study Mahaye (2020) suggests that to reach vulnerable populations in Sub-Saharan Africa, institutions may consider also using multi-modalities (e.g., television, radio, mobile phone SMSes) for the delivery of lessons. Nonetheless, more studies assessing the educational impact of such measures are needed.

\section{The development of on-campus risk management strategy for COVID-19}

To mitigate the risk of COVID-19 spread on campus, staff members suggested a need for a risk management strategy, which amongst others put in place the following measures:

- $\quad$ Establish COVID-19 screening and testing stations on campus;

- Monitor staff access to the university premises;

- The provision of Personal Protective Equipment (PPE) on both the staff and students;

- The development of COVID-19 awareness programmes on campus;

- $\quad$ Regularly disinfecting or sanitizing lecture halls and offices;

- The implementation of a "phased-in-approach" for the repatriation of students on campus;

- Flexible working hours for staff members to avert overcrowding on campus; and

- $\quad$ Offer staff members with comorbidity conditions special leeway to work from home.

Recent studies suggest that some of the above measures have been put in place elsewhere and yielded positive results (Cowling et al. 2020; Ferguson et al. 2020). However, whether similar measures would yield positive results in this context cannot be ascertained at this stage. Postimplementation evaluation studies may be necessary. Even so, some proof exists that such measures especially a combination of them can yield positive results for schools and colleges (Viner et al. 2020).

\section{Provision of online psychological services and need for University Employee Wellness Programme}

Considering the impact of COVID-19 on the staff members' wellbeing, the results further displayed that the university needed to avail online trauma debriefing and counselling services for staff members. Seemingly, the university needed to avail Employee Wellness Programme on-campus for the staff post-COVID-19 lockdown. The psychological impact of COVID-19 on people is not unique to this context as studies elsewhere have reported similar findings (WHO 2020). Therefore, availing online COVID-19 psychological debriefing and stress management 
services promises to be another strategy that could promote staff's psychological wellbeing and thereof promote their productivity during-and-after the lockdown.

How all of the above strategies could yield desirable outcomes in this university context during the COVID-19 pandemic can only be left for their implementation and evaluation. However, some promises are found in reports suggesting that the availability of efficient ICT infrastructure can make remote learning possible when plans, communication, and related resources are put in place on time (Mahaye 2020; Viner et al. 2020; Lin et al. 2020). Seemingly, proof exists that some of the COVID-19 preventative and control measures could yield positive results (Cowling et al. 2020; Ferguson et al. 2020). How historically disadvantaged universities manage to embrace some of the proposed strategies including supporting students who might not have ICT equipment and/or access to internet services remains a challenge to be championed. In retrospect, availing of ICT infrastructure only to staff may not necessarily yield positive results because learning is a two-way street between lecturers and students. It, therefore, becomes prudent for the government and other important role players especially the private sector to extend their arms of service to previously disadvantaged universities as they struggle to adjust during the pandemic. The government could also consider benchmarking on the suggested to guide their strategy of supporting higher institutions of learning during the pandemic. This could perhaps keep students on track to ensure that when they return to universities, much would not have been lost (Ray 2020).

\section{STUDY IMPLICATIONS}

The present study findings imply that for staff members to continue being productive and efficient in the present setting, the university needed to consider implementing efficient communication strategies. Thus, providing staff members or students with ICT equipment as well as procure efficient ICT infrastructure and services. Perhaps, the university may consider seeking support from the government and donors to champion this potential challenge. Additionally, the university needed to implement compensatory academic measures to mitigate a possible high student failure rate secondary to the COVID-19 impact on learning. The university should avail online psychological debriefing and stress management services to the staff members who have been mentally impacted by COVID-19. Whilst setting up Employee Wellness Programmes on campus for use post-lockdown, and for future use in responding to similar crises. If historically disadvantaged universities considered implementing some of the proposed strategies, the overall study findings seem to suggest that staff members' productivity, efficiency and mental and physical wellbeing could be enhanced. However, there's a need for 
more studies to explore and establish the effectiveness of similar strategies in other disadvantaged African universities for better response to COVID-19 pandemic.

For future preparedness, study findings magnify the importance of institutions of higher learning's need to firstly, put in place contingency plans for efficient communication, and secondly, invest in efficient ICT infrastructure for remote learning, teaching, and research. This would be a proactive strategy to prevent student education and career prospects from being negatively impacted by similar occurrences in the future. Also, governments in Africa may consider capacitating and regulating institutions of higher learning in terms of their capabilities to offer remote learning, teaching and research. Generally, COVID-19 presents institutions of higher learning with a challenge yet an opportunity to amongst others reflect on the impact of COVID-19 on their traditional systems of teaching, learning, and research, and where possible, benchmark on some of the suggested strategies, revise and update their systems for future preparedness (Aborode et al. 2020). Inclusively, there is a need for revised employee wellness programmes that integrates online psychological services.

\section{STUDY LIMITATIONS}

Notwithstanding the proposed strategies, methodologically, the study relied on the nonprobability convenience sampling strategy, which could have influenced the outcomes of the study. Therefore, the statistical power of the study is somewhat affected, meaning the results may not necessarily be generalised to all university staff members. Seemingly, the findings may not necessarily be extrapolated to all historically disadvantaged universities because it was conducted in one university. Caution is therefore needed when interpreting or implementing some of the suggested strategies in historically disadvantaged universities.

\section{CONCLUSION}

This study reported on the strategies suggested by staff members in a historically disadvantaged university, intended to enhance their wellbeing and administration of academic activities during-and-after the national COVID-19 pandemic. In the main, five generic strategies were proposed amongst which a COVID-19 communication strategy, provision of efficient ICT infrastructure strategy, compensatory academic measure as a strategy, on-campus COVID-19 risk management strategy, online psychological services and an on-campus employee wellness programme strategy were identified by participants. Although these findings are important for the historically disadvantaged university as they respond to the pandemic, for methodological reasons, the findings may not necessarily be taken to mean is the view of all staff in this 
particular university or would be applicable to all universities. Therefore, caution may need to be exercised when reading and/or implementing suggested strategies. More research to establish similar measures and their effectiveness in other universities is needed. Nonetheless, this article contributes to the global fight against the COVID-19 pandemic in a historically disadvantaged university.

\section{DECLARATIONS}

No funding was received for this project. The authors declare no conflicts of interest.

\section{AUTHOR CONTRIBUTIONS}

Conceptualisation, $M M$ and $M T$; methodology, $M M$ and $M T$; formal analysis, $M M, M T$ and $M P$; investigation, All; resources, $M M$ and $M T$; data curation, $M M$ and $M P$, preparing the original draft, $M M$; review and editing, All.

\section{ACKNOWLEDGEMENTS}

We wish to thank the university management for granting permission for the undertaking of this project. More importantly, this project could not have been possible without staff members who participated in it. We truly appreciate your time. Re ya leboga!!!

\section{REFERENCES}

Aborode, A., O. Anifowoshe, T. I. I. Ayodele, A. R. Iretiayo, and O. O. David. 2020. "Impact of COVID-19 on education in Sub-Saharan Africa." Preprints 2020. doi: 10.20944/ preprints202007.0027.v1.

Cowling, B. J., S. T. Alim, T. W. Y. Ng, T. K. Tsang, J. C. M. Li, M. W. Fong, Q. Liao, M. Y. W. Kwan, S. L. Lee et al. 2020. "Impact assessment of non-pharmaceutical interventions against coronavirus disease 2019 and influenza in Hong Kong: An observational study." Lancet Public Health 5: 279-88 doi.org/10.1016/S2468-2667(20)30090-6.

Ferguson, N., M. D. Laydon, G. Nedjati-Gilani, N. I. Kylie Ainslie, M. Baguelin, S. Bhatia, A. Boonyasiri, Z. Cucunubá, G. Cuomo-Dannenburg et al. 2020. "Report 9: Impact of nonpharmaceutical interventions (NPIs) to reduce COVID-19 mortality and healthcare demand." Imperial College COVID-19 Response Team. https://doi.org/10.25561/77482.

Helmich, R. C. and B. R. Bloem. 2020. "The impact of the COVID-19 pandemic on Parkinson's disease: Hidden sorrows and emerging opportunities.” Journal of Parkinson's Disease 10(2): 351-354. https://doi.org/10.3233/JPD-202038.

King, N. and C. Horrocks. 2010. Interviews in qualitative research. Sage, London.

Lin, R., J. T. H. Lee, and D. C. B. Lye. 2020. "From SARS to COVID-19: The Singapore journey." Medical Journal of Australia 212(11): 497-502. https://doi.org/10.5694/mja2.50623.

Mahaye, N. E. 2020. "The impact of COVID-19 pandemic on South African education: Navigating forward the pedagogy of blended learning pedagogy of blended learning." International Journal of Educational Science 6(2): 341-348.

Ray, K. 2020. What is remote learning? https:/www.techlearning.com/how-to/what-is-remotelearning. (Accessed 29 April 2020).

South African Government Gazette. 2020. "Regulations issued in terms of section 27(2) of the Disaster 
Management Act, 2002.” https://www.gov.za/sites/default/files/gcis_document/ 202004/43258rg11098gon480s.pdf. (Accessed 29 April 2020).

UNESCO see United Nations Education Scientific and Cultural Organization.

United Nations. 2020. Policy Brief: Impact of COVID-19 in Africa. https://drive.google.com/ file/d/17JYRwXNgsZ3PUInzcF2o3RNLkUEm5qts/view?usp=drivesdk Wiley Online Library. (Accessed 29 April 2020).

United Nations Education Scientific and Cultural Organization. 2020. COVID-19 Educational Disruption and Response. https://en.unesco.org/covid19/educationresponse. (Accessed 29 April 2020).

Viner, R., M. S. J. Russell, H. Croker, J. Packer, J. Ward, C. Stansfield, O. Mytton, C. Bonell, and R. Booy. 2020. "School closure and management practices during coronavirus outbreaks including COVID-19." A Rapid Systematic Review 3(4): 397-404. doi.org/10.1016/ S2352-4642(20)30095-

WHO. 2020. Naming the coronavirus disease (COVID-19) and the virus that causes it. https://www.who.int/emergencies/diseases/novel-coronavirus-2019/technical-guidance/namingthe-coronavirus-disease-(covid-2019)-and-the-virus-that-causes-it. (Accessed 29 April 2020).

Wyres, M. and N. Taylor. 2020. "Covid-19: Using simulation and technology-enhanced learning to negotiate and adapt to the ongoing challenges in UK healthcare education." BMJ Simulation and Technology Enhanced Learning 0: 1-3. doi.org/10.1136/bmjstel-2020-000642.

\section{APPENDIX}

Table 2: Strategies to improve staff members' wellbeing and administration of academic programs during-and-after COVID-19 national lockdown

\begin{tabular}{|c|c|}
\hline Generic Strategies & $\begin{array}{l}\text { Supporting participant extracts } \\
\text { Key: use of an asterisk }\left({ }^{*}\right) \text { denote revisions were made for anonymity } \\
\text { purposes }\end{array}$ \\
\hline $\begin{array}{l}\text { 1. Development of COVID-19 } \\
\text { communication strategy }\end{array}$ & $\begin{array}{l}\text { - The university should improve its communication strategy. } \\
\text { - } \quad \text { Better communication from management, we never have any certainty } \\
\text { about what is going on. } \\
\text { - The University should keep constant communication with staff members } \\
\text { and students about the developments } \\
\text { - Proper guidance and communication from the university regarding } \\
\text { expectations of support staff. To date, the focus has only been on } \\
\text { academics. } \\
\text { *The institution* should keep all staff members abreast of developments } \\
\text { or measures in place thus far. The silence causes a lot of uncertainties } \\
\text { and anxieties. Keep us informed on a weekly basis, we sometimes hear } \\
\text { information from the media, and some communique reaches students } \\
\text { first. } \\
\text { Consultation with the general University community with regards to } \\
\text { COVID } 19 \text { is important. Most people with crucial information are left out. } \\
\text { - Proper guidelines and clear instructions } \\
\text { Managers need to always check on subordinates and hear from them } \\
\text { how they are doing maybe through WhatsApp or SMSes }\end{array}$ \\
\hline $\begin{array}{l}\text { 2. Provision of efficient Information } \\
\text { Communication Technologies } \\
\text { (ICTs) infrastructure for remote } \\
\text { learning and research }\end{array}$ & $\begin{array}{l}\text { - To improve online services and be responsive to the "new normal" } \\
\text { - Internet access should be made more accessible to both students and } \\
\text { - } \quad \text { The unf to enable us to work remotely. } \\
\text { - } \quad \text { The the process is moving a bit slow } \\
\text { research } \\
\text { - Online teaching should be the primary mode of teaching. } \\
\text { - Train staff members with other applications that we can use to teach } \\
\text { online and provide us with all the necessary equipment (microphones, } \\
\text { laptops, airtime to call ICT staff when we experience technical issues) } \\
\text { when we are hit by another pandemic. } \\
\text { - Continuous support could be very helpful, virtual seminars, and not just a } \\
\text { once in while survey }\end{array}$ \\
\hline
\end{tabular}




\begin{tabular}{|c|c|}
\hline Generic Strategies & $\begin{array}{l}\text { Supporting participant extracts } \\
\text { Key: use of an asterisk }{\left({ }^{*}\right)}^{*} \text { denote revisions were made for anonymity } \\
\text { purposes }\end{array}$ \\
\hline & $\begin{array}{l}\text { - The University should have implemented online teaching a long time } \\
\text { ago. } \\
\text { Yes, provide academic staff with resources to assist with online teaching } \\
\text { and research }\end{array}$ \\
\hline $\begin{array}{l}\text { 3. Implementation of compensatory } \\
\text { academic measures for students }\end{array}$ & $\begin{array}{l}\text { - } \quad \text { Maybe by extending the year calendar. } \\
\text { - Starts contact learning for small groups such as postgraduates, and } \\
\text { slowly move forward from there, for now, COVID-19 is a part of our } \\
\text { reality, we must find ways to keep moving forward. } \\
\text { - I wish the university could expedite the repatriation of staff into campus } \\
\text { so that some aspects of my role which cannot be done at home are } \\
\text { taken care of } \\
\text { - } \text { After the lockdown, students mustn't be rushed to write examinations or I } \\
\text { fear the pass rate may reduce to a significant degree. } \\
\text { - If the university can allow the final year students to come back on } \\
\text { campus, this would relieve the pressure/stress that is on everyone as } \\
\text { final year students are worried about their future and always asking } \\
\text { questions. } \\
\text { - Call postgraduate students back } \\
\text { Scholarship for doctoral study. Financial support to attend specialized } \\
\text { workshops, academic research seminars and conferences both locally } \\
\text { and internationally. } \\
\text { Allow some students to come back and have normal teaching and } \\
\text { learning } \\
\text { If possible, can they please extend the academic year to accommodate } \\
\text { all the work, we are supposed to work on this year without rushing. } \\
\text { Online learning new and we are still adapting. It is not very } \\
\text { accommodating at the moment. } \\
\text { As the numbers of students who can occupy a venue at a given point in } \\
\text { time will be minimal. I suggest we work at getting more academics on } \\
\text { board to prevent burnouts of the currently understaffed departments. }\end{array}$ \\
\hline $\begin{array}{l}\text { 4. Development of on-campus risk } \\
\text { management strategy for COVID- } \\
19\end{array}$ & $\begin{array}{l}\text { - } \quad \text { Precautionary measures should be put in place to ensure the safety of } \\
\text { - } \quad \text { Yes, university community } \\
\text { - } \quad \text { Social distancing, } \\
\text { - Monitored access to the university would have been more ideal than a } \\
\text { complete shutdown. The lockdown was initially for } 21 \text { days so it's } \\
\text { reasonable to assume that not everyone packed out their offices. } \\
\text { - Take serious note of staff members with comorbidity, give them } \\
\text { - } \quad \text { Allow us to work from home even after we're back from home, and only } \\
\text { - } \quad \text { Healthy lifestyle needs to be maintained } \\
\text { - The University should adhere to the specified regulations }\end{array}$ \\
\hline $\begin{array}{l}\text { 5. Provision of online psychological } \\
\text { services and need for University } \\
\text { Employee Wellness Program }\end{array}$ & 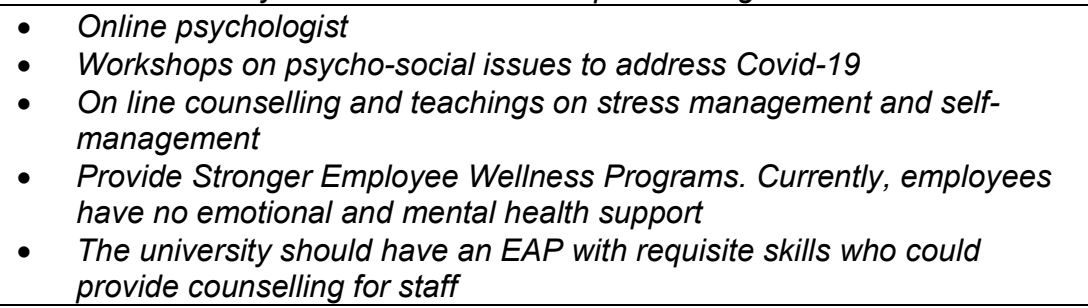 \\
\hline
\end{tabular}

